\title{
Synthesis of C-Cl-codoped titania/attapulgite composites with enhanced visible-light photocatalytic activity
}

\author{
Lijuan Deng a,b, Yi Xie a,\#, Gaoke Zhang a,b,* \\ a State Key Laboratory of Silicate Materials for Architectures, Wuhan University of Technology, Wuhan 430070, Hubei, China \\ b Hubei Key Laboratory of Mineral Resources Processing, Hubei Provincial Collaborative Innovation Center for High Efficient Utilization of Vanadium \\ Resources, and School of Resources and Environmental Engineering, Wuhan University of Technology, Wuhan 430070, Hubei, China
}

\section{A R T I C L E I N F O}

\section{Article history:}

Received 21 October 2016

Accepted 23 December 2016

Published 5 February 2017

\section{Keywords:}

Anatase

Rutile

Brookite

Attapulgite

C-Cl-codoped titania

Visible light

\begin{abstract}
A B S T R A C T
We demonstrate the synthesis of C-Cl-codoped titania/attapulgite $\left(\mathrm{TiO}_{2} / \mathrm{ATT}\right)$ composites containing a mixture of $\mathrm{TiO}_{2}$ phases by a facile sol-gel method at $70{ }^{\circ} \mathrm{C}$ using titanium tetraisopropoxide as the $\mathrm{TiO}_{2}$ precursor and ATT as a support for the $\mathrm{TiO}_{2}$ nanoparticles. The photocatalytic activity of the $\mathrm{C}$-Cl-codoped $\mathrm{TiO}_{2} / \mathrm{ATT}$ composites with mixed anatase/brookite/rutile phases obtained at $\mathrm{pH}$ = 3.0 was much higher than that of commercially available Degussa P25 for the photocatalytic degradation of acid red G under visible-light irradiation. The excellent photocatalytic activity of the developed composite originates from the nonmetal codoping, which extends the absorption edge of $\mathrm{TiO}_{2}$ into visible region, and the presence of multiple phases, which slow the recombination of photoexcited electron/hole pairs. The formation of hydroxyl radicals during the photocatalytic degradation process was detected by photoluminescence probing using terephthalic acid. A mechanism for photocatalysis over the C-Cl-codoped $\mathrm{TiO}_{2}$ /ATT composites was proposed.
\end{abstract}

(C) 2017, Dalian Institute of Chemical Physics, Chinese Academy of Sciences. Published by Elsevier B.V. All rights reserved.

\section{Introduction}

Heterogeneous photocatalysis using a semiconductor has been reported to promote the degradation and total mineralization of a wide range of pollutants in water and air [1-3]. Among the various semiconductors, titania $\left(\mathrm{TiO}_{2}\right)$ has attracted extensive attention because of its good photocatalytic activity, high photochemical stability, low cost, and environmental friendliness $[4,5]$. However, one of the problems of $\mathrm{TiO}_{2}$-based photocatalysis is the rapid recombination of photoexcited electron/hole pairs, which leads to low catalytic activity. Therefore, it is critical to decrease the recombination rate of photogenerated charge carriers to enhance the photocatalytic activity of
$\mathrm{TiO}_{2}$ for practical application and commercialization. One of the solutions to this issue is to fabricate a $\mathrm{TiO}_{2}$-based heterojunction structure using narrow-band-gap semiconductor with band potentials that match those of $\mathrm{TiO}_{2}$. This allows the photogenerated carriers from the narrow band gap semiconductor to transfer to $\mathrm{TiO}_{2}$ via the heterojunction interface, which leads to efficient charge separation [6]. Zhou et al. [7,8] improved the photocatalytic activity of $\mathrm{TiO}_{2}$ by modification with metal oxides such as $\mathrm{Ag}_{2} \mathrm{O}, \mathrm{W}_{2} \mathrm{O}_{3}, \mathrm{NiO}$, and $\mathrm{PdO}$, because of their electron capture and visible-light sensitization capability. Composites made of mixed $\mathrm{TiO}_{2}$ phases show enhanced photocatalytic activity compared with the corresponding pure phase because of the suppressed recombination of photogenerated electrons

\footnotetext{
* Corresponding author. Tel: +86-27-87651816; Fax: +86-27-87887445; E-mail: gkzhang@whut.edu.cn

\# Corresponding author. Tel: +86-27-87651816; Fax: +86-27-87887445; E-mail: xiey@whut.edu.cn

This work was supported by the National Basic Research Program of China (973 Program, 2007CB613302) and the Natural Science Foundation of Hubei Province (2016CFA078).

DOI: 10.1016/S1872-2067(17)62774-8 | http://www.sciencedirect.com/science/journal/18722067 | Chin. J. Catal., Vol. 38, No. 2, February 2017
} 
and holes [9].

The use of $\mathrm{TiO}_{2}$ as a photocatalyst for sunlight-induced chemical conversions is hampered by the fact that $\mathrm{TiO}_{2}$ only absorbs the ultraviolet (UV) region of the solar spectrum arriving at the earth's surface [10]. Numerous studies including the doping or modification of $\mathrm{TiO}_{2}$ with metal or nonmetal species such as Fe [11], N [12], and C [13] have recently been conducted to improve the optical response of $\mathrm{TiO}_{2}$ in the visible region. However, the doping process of nonmetal elements always involves thermal treatment at high temperatures or hydrothermal treatment for an extended period, which is unfavorable in terms of energy consumption [14].

In addition, the potential of nanosized photocatalysts in water or wastewater treatment has been greatly limited by the difficulty and high cost of the separation of the photocatalyst nanoparticles (NPs) from the water being treated. To solve this problem, there have been a number of attempts to immobilize $\mathrm{TiO}_{2}$ NPs on various substrates, particularly inorganic ones including glass, metals, silicon slides, stones, and pillared clays $[15,16]$. These methods can be used to develop supported heterogeneous catalysts without lowering photocatalytic efficiency [17]. Despite many previous reports on the photodegradation of pollutants in aqueous solution over pillar-supported $\mathrm{TiO}_{2}$ photocatalysts under UV irradiation [18], few studies on that under visible light irradiation are available.

Here we develop a facile sol-gel procedure to synthesize C-Cl-codoped $\mathrm{TiO}_{2}$ /attapulgite $\left(\mathrm{TiO}_{2} / \mathrm{ATT}\right.$ ) photocatalysts, in which the mixed phases of rutile, anatase, and brookite improve the separation of photoexcited electrons and holes. In addition, the nonmetal doping facilitates the utilization of visible light and the unique porous structure of ATT acts as a catalyst support and environmental adsorbant [19]. The photocatalytic activities of the as-obtained composites in degradation of acid red G (ARG) under visible-light irradiation are studied. The effect of formation $\mathrm{pH}$ on the phases, optical spectra, and photocatalytic activity of the resulting $\mathrm{C}-\mathrm{Cl}$-codoped $\mathrm{TiO}_{2} / \mathrm{ATT}$ composites is investigated. Interestingly, the composites obtained at $\mathrm{pH}=3.0$ displayed high absorbance in the visible region, much higher photocatalytic efficiency than that of Degussa P25, and excellent stability in photocatalysis even after recycling five times.

\section{Experimental}

\subsection{Synthesis of $\mathrm{TiO}_{2} / \mathrm{ATT}$ photocatalysts}

The $\mathrm{TiO}_{2} / \mathrm{ATT}$ composites were prepared via a simple sol-gel method. The ATT clay was obtained from Anhui, China. All other chemicals were analytical grade and used as received without further purification. Deionized water was used throughout the experiments. The pillaring agent, which was a solution of partially hydrolyzed Ti-polycations, was prepared by adding titanium tetraisopropoxide (TTIP) to $\mathrm{HCl}$ solution (6

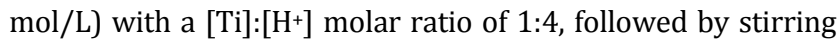
for $3 \mathrm{~h}$ at room temperature (RT). In parallel, an aqueous suspension of ATT (1 wt\%) was prepared by dispersing ATT in deionized water and vigorously stirring for $5 \mathrm{~h}$. The pillaring
Table 1

Relative contents and crystal sizes of the anatase, rutile and brookite phases in the composites.

\begin{tabular}{|c|c|c|c|c|c|c|c|}
\hline \multirow{2}{*}{ Sample } & \multirow{2}{*}{$\mathrm{pH}$} & \multicolumn{2}{|c|}{ Anatase } & \multicolumn{2}{|c|}{ Brookite } & \multicolumn{2}{|c|}{ Rutile } \\
\hline & & (wt\%) & $D(\mathrm{~nm})$ & (wt\%) & $D(\mathrm{~nm})$ & (wt\%) & $D(\mathrm{~nm})$ \\
\hline $\bar{A}$ & 1.0 & 66.21 & 6.50 & - & - & 33.79 & 10.99 \\
\hline B & 3.0 & 41.07 & 11.04 & 37.76 & 13.79 & 21.17 & 17.74 \\
\hline $\mathrm{C}$ & 5.0 & 88.60 & 7.01 & - & - & 11.40 & 16.62 \\
\hline D & 7.0 & 93.11 & 8.43 & - & - & 6.89 & 15.61 \\
\hline $\mathrm{E}$ & 9.0 & 92.48 & 7.56 & - & - & 7.52 & 17.65 \\
\hline
\end{tabular}

solution was then added dropwise to the ATT aqueous suspension at $70{ }^{\circ} \mathrm{C}$ under vigorous stirring with a ratio of Ti/ATT of up to $10 \mathrm{mmol} / \mathrm{g}$. The resulting mixture was aged for $15 \mathrm{~h}$. $\mathrm{NaOH}$ solution was then added to adjust the $\mathrm{pH}$ from 3.0 to 9.0 and the mixture was aged for an additional $2 \mathrm{~h}$. The mixture was centrifuged at $3600 \mathrm{r} / \mathrm{min}$ to give a precipitate, which was dried in air, ground into a powder in an agate mortar. Samples are denoted as A-E according to the $\mathrm{pH}$ used (Table 1).

\subsection{Characterization}

The phase and crystallinity of the as-prepared samples were characterized by powder X-ray diffraction (XRD) on a D/MAX-RB diffractometer using $\mathrm{Cu} K_{\alpha}$ radiation at $40 \mathrm{kV}$ and $50 \mathrm{~mA}$. The integrated intensities $(I)$ of the anatase $\mathrm{A}(101)$, brookite $\mathrm{B}(121)$, and rutile $\mathrm{R}(110)$ peaks obtained from the numerical treatment were used to calculate the weight fractions $(x)$ of the three phases (Eqs. (1)-(3)), and the average crystallite sizes $(D)$ were estimated by the Scherrer equation (Eq. (4)).

$$
\begin{gathered}
x_{\mathrm{Ana}}=0.886 I_{\mathrm{A}(101)} /\left(0.886 I_{\mathrm{A}(101)}+I_{\mathrm{R}(110)}+2.721 I_{\mathrm{B}(121)}\right) \\
x_{\mathrm{Rut}}=I_{\mathrm{R}(101)} /\left(0.886 I_{\mathrm{A}(101)}+I_{\mathrm{R}(110)}+2.721 I_{\mathrm{B}(121)}\right) \\
x_{\mathrm{Bro}}=2.721 I_{\mathrm{B}(121)} /\left(0.886 I_{\mathrm{A}(101)}+I_{\mathrm{R}(110)}+2.721 I_{\mathrm{B}(121)}\right) \\
D=0.90 \lambda /(\beta \cos \theta)
\end{gathered}
$$

where $\lambda$ is the wavelength of $\mathrm{Cu} K_{\alpha}$ radiation (1.5418 $\AA$ ), $\beta$ is the full width at half-maximum of the corresponding diffraction peak, and 0.90 is the Scherrer constant [20].

The morphologies and microstructure of the samples were observed by scanning electron microscopy (SEM; JSM-5610LV, Japan), transmission electron microscopy (TEM) and high-resolution TEM (HRTEM; JEM-2100F, Japan) using an accelerating voltage of $200 \mathrm{kV}$. An energy-dispersive X-ray spectrometer (EDS; Phoenix, Japan) attached to the SEM was used to verify element constituents. Absorption spectra were collected on a UV-Vis spectrophotometer (UV2550, Shimadzu) using $\mathrm{BaSO}_{4}$ as a reflectance standard in diffuse reflectance experiments. Raman analysis was performed on a Renishaw InVia confocal Raman microprobe with 514-nm excitation by a He-Ne laser at RT. The chemical bonds on the surface of the samples were analyzed by Fourier transform infrared (FT-IR) spectroscopy (Nexus, Thermo Nicolet). Specific surface area was measured by the Brunauer-Emmett-Teller (BET) method using a nitrogen adsorption apparatus (Autosorb-1, Quantachrome). The pore volume and pore diameter distribution were derived from desorption branches of the isotherms using the Barrett-JoynerHalenda (BJH) model. Binding energies (BE) were measured by 
X-ray photoelectron spectroscopy (XPS) using a VG Multilab 2000 spectrometer. The hydroxyl radical $(\bullet \mathrm{OH})$ concentration during the photocatalytic degradation process was detected by a photoluminescence probing technique using terephthalic acid (TA). We measured $\bullet \mathrm{OH}$ trapping fluorescence spectra with a fluorescence spectrophotometer (RF-5301PC, Shimadzu) using the 280-nm line of a Xe lamp as the excitation source at RT.

\subsection{Photocatalytic activity measurments}

The photocatalytic activities of the samples were evaluated by the decomposition of ARG in aqueous solution under visible-light irradiation. Typically, photocatalyst $(0.15 \mathrm{~g})$ was added to ARG solution (50 mg/L, $100 \mathrm{~mL}$ ) [21], which was then stirred for $10 \mathrm{~min}$ in the dark to ensure that an adsorption/desorption equilibrium was established between the photocatalyst and ARG molecules before irradiation. The suspension was then exposed to a 300-W Xe lamp with a $400-\mathrm{nm}$ cutoff filter by fixing the distance between the liquid surface and light source at about $8 \mathrm{~cm}$ in all the experiments. At defined time intervals, the concentration of the ARG solution was analyzed using a UV-Vis spectrophotometer (UV751GD) at the maximum absorption wavelength of ARG of $505 \mathrm{~nm}$ [21].

The mineralization of ARG was monitored by measuring the total organic carbon (TOC) content with a multi N/C 2100 TOC analyzer (Analytic Jena AG). The stability of the $\mathrm{TiO}_{2} / \mathrm{ATT}$ composites during the photocatalytic degradation experiments was evaluated by reusing the photocatalysts for the decomposition of ARG under the same conditions.

\section{Results and discussion}

\subsection{Sample characterization}

\subsubsection{XRD analysis}

The XRD patterns of the resulting $\mathrm{C}-\mathrm{Cl}$-codoped $\mathrm{TiO}_{2} / \mathrm{ATT}$ composites in Fig. 1 indicate that $\mathrm{pH}$ affected the phases present. The (110), (200), (040), and (400) XRD peaks of ATT gradually disappeared as the $\mathrm{TiO}_{2}$ NPs formed pillars, suggesting that the layered structure of ATT was gradually destroyed with increasing $\mathrm{pH}$. Peaks of the anatase phase of $\mathrm{TiO}_{2}$ are observed in the diffraction patterns of all $\mathrm{TiO}_{2}$ /ATT composites, and increasing $\mathrm{pH}$ strengthens the intensity of these peaks relative to the diffraction intensities of other phases. Peaks of both anatase and rutile phases are detected in the XRD patterns of samples A, C, D, and E, while sample B fabricated at $\mathrm{pH}=3.0$ contained a mixture of brookite, anatase, and rutile phases. The brookite phase was detected only in sample B, which might be caused by the presence of appropriate concentrations of $\mathrm{Na}^{+}$ and $\mathrm{Cl}^{-}$used in the synthesis reaction [22].

Table 1 reports the fraction and crystallite sizes of various phases of the as-synthesized samples, showing that the rutile fraction decreases overall with increasing $\mathrm{pH}$. Rutile structure is the equilibrium structure of $\mathrm{TiO}_{2}$, in which titanium atoms link with each other in straight chains rather than the linked chains of edge-sharing octahedra typical of anatase. This indicates that the formation rate of the rutile phase is relatively

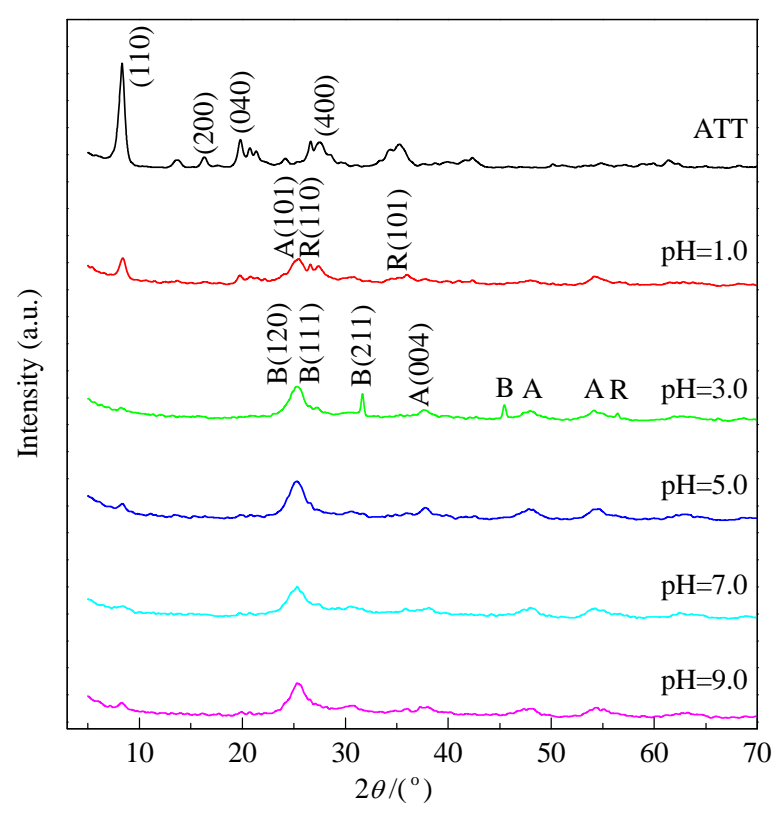

Fig. 1. XRD patterns of ATT and $\mathrm{C}-\mathrm{Cl}$-codoped $\mathrm{TiO}_{2} / \mathrm{ATT}$ composites obtained at different $\mathrm{pH}$ values.

low. In strongly acidic solution, the condensation rate is slow enough that the formation of the rutile phase is kinetically favored [23], which results in a higher content of the rutile phase in sample B than that of the other samples obtained at higher $\mathrm{pH}$.

\subsubsection{Morphological and microstructural analyses}

Fig. 2(a)-(c) depict SEM images of ATT, pure $\mathrm{TiO}_{2}$ (P25), and a representative $\mathrm{TiO}_{2} /$ ATT composite (sample B). The ATT clay is a randomly oriented network of densely packed fibers. The diameter of a single fiber is less than $40 \mathrm{~nm}$ and the fiber length ranges from several hundred nanometers to several micrometers (Fig. 2(a)). The $\mathrm{TiO}_{2}$ NPs possess diameters ranging from 100 to $300 \mathrm{~nm}$ (Fig. 2(b)). The surface of the $\mathrm{TiO}_{2} /$ ATT composite contains numerous $\mathrm{TiO}_{2}$ NPs (Fig. 2(c)).

HRTEM was used to further investigate the morphology of sample B (Fig. 2(d)), revealing that the $\mathrm{TiO}_{2}$ NPs were uniformly distributed on the surface of fiber-like ATT. The particle size of $\mathrm{TiO}_{2}$ was around $13 \mathrm{~nm}$, which agrees well with the value estimated from the XRD data (Table 1). Lattice spacings of $0.329,0.347$, and $0.362 \mathrm{~nm}$ were observed (Fig. 2(e)), which agree with the (101) plane of the rutile phase, and the (111) and (201) planes of the brookite phase of $\mathrm{TiO}_{2}$ particles, respectively. The lattice spacings of 0.352 and $0.354 \mathrm{~nm}$ correspond to the (101) plane of the anatase phase.

\subsubsection{Elemental analysis}

EDS demonstrated the presence of $\mathrm{C}, \mathrm{Na}, \mathrm{Cl}, \mathrm{Ti}$, and $\mathrm{O}$ in the representative composite sample B (Fig. 2(f)). The $\mathrm{C}$ might originate from the titanium alkoxide precursor. The chemical states of $\mathrm{C} 1 s, \mathrm{Cl} 2 p$, Ti $2 p$, and $01 s$ were further investigated using high-resolution XPS (Fig. 3). The $\mathrm{C} 1 s$ band could be deconvoluted into two peaks. The peak at around $282.12 \mathrm{eV}$ could be ascribed to either $\mathrm{O}-\mathrm{Ti}-\mathrm{C}[24]$ or Ti-C bonds, indicating that 

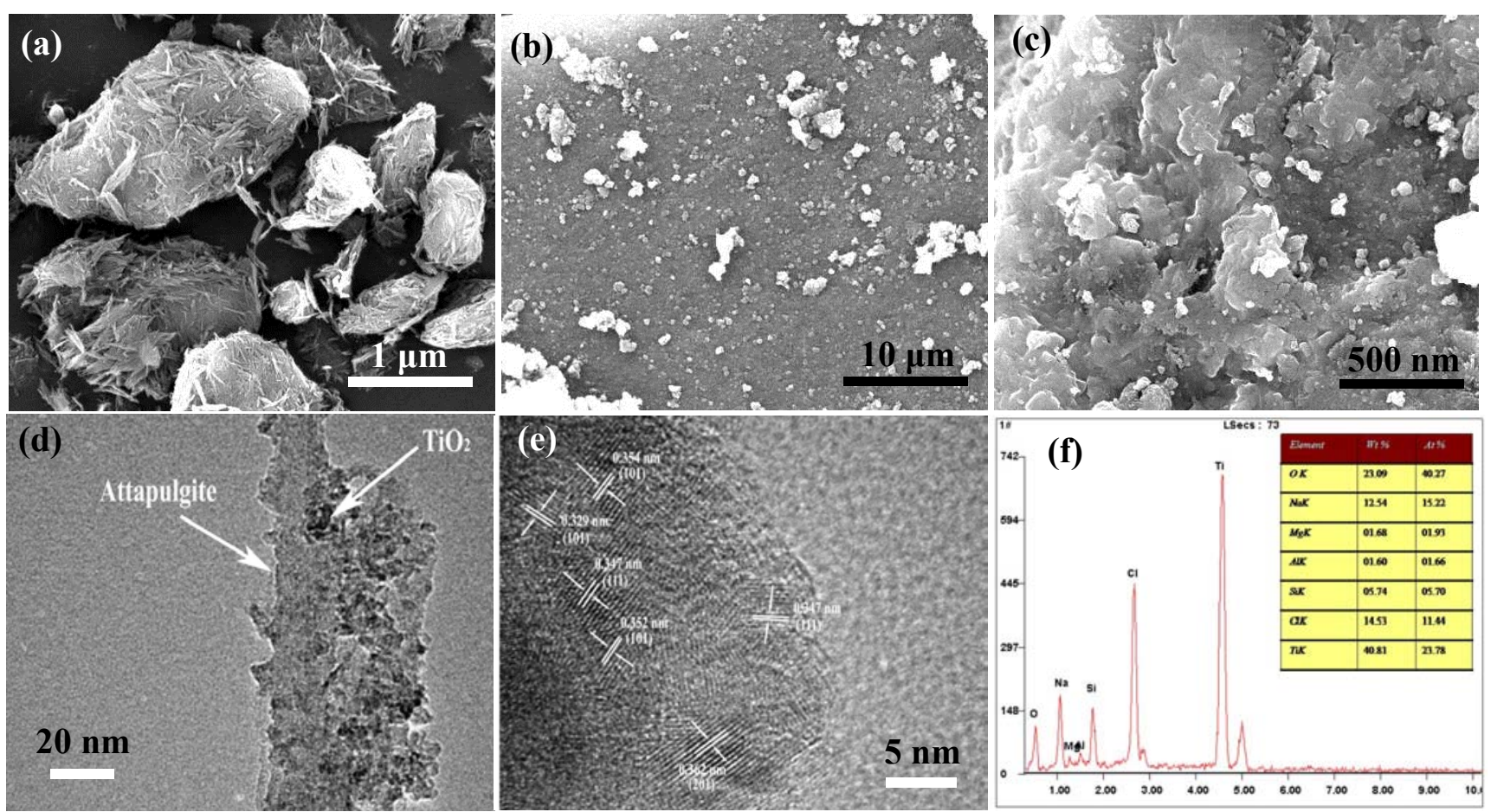

Fig. 2. SEM images of ATT (a), $\mathrm{TiO}_{2}(\mathrm{~b})$, and the $\mathrm{C}-\mathrm{Cl}$-codoped $\mathrm{TiO}_{2} / \mathrm{ATT}$ composite obtained at pH 3.0 (c); TEM image (d), HRTEM image (e), and EDS analysis (f) of the $\mathrm{C}$-Cl-codoped $\mathrm{TiO}_{2} / \mathrm{ATT}$ composite obtained at $\mathrm{pH} 3.0$ (sample B).
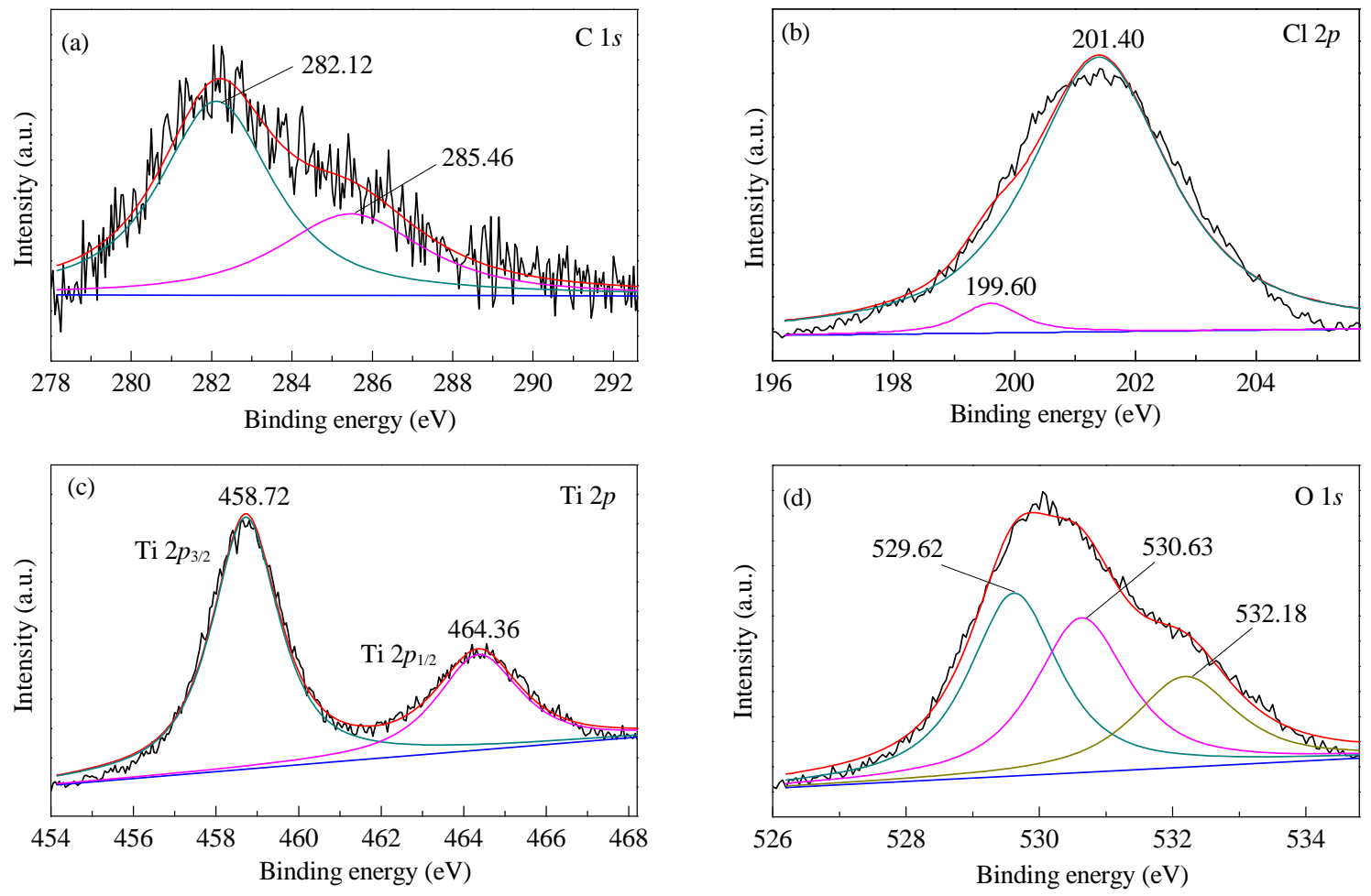

Fig. 3. High-resolution C $1 s$ (a), $\mathrm{Cl} 2 p$ (b), Ti $2 p$ (c) and $01 s$ (d) XPS analysis of sample $\mathrm{B}$.

$\mathrm{TiO}_{2}$ has been doped with $\mathrm{C}$ [25]. The peak at around $285.46 \mathrm{eV}$ could be attributed to adventitious $C$ species present during from XPS measurement [26]. Reports on XPS analyses of doped $\mathrm{Cl}$ are contradictory. For example, the $\mathrm{Cl} 2 p$ spectrum of a re- ported C-Cl-codoped $\mathrm{TiO}_{2}$ sample displayed two BE contributions at around 197.9 and $199.5 \mathrm{eV}$, which were respectively assigned to $\mathrm{Cl}^{-}$physically adsorbed on $\mathrm{TiO}_{2}$ and $\mathrm{Cl}$ incorporated into the crystal lattice [27]. Conversely, $\mathrm{Cl} 2 p$ data deconvoluted 
into one strong peak at around $198.2 \mathrm{eV}$ and another weak peak over $199 \mathrm{eV}$ were attributed to incorporated and chemisorbed states of $\mathrm{Cl}$, respectively, in a $\mathrm{Cl}$-doped $\mathrm{TiO}_{2}$ photocatalyst [28]. In our work, the $\mathrm{Cl} 2 p$ peak was asymmetric and could be deconvoluted into two contributions at around 199.60 and $201.40 \mathrm{eV}$ (Fig. 3(b)). The origin of the main contribution at $201.40 \mathrm{eV}$ is unknown, and the minor peak at $199.60 \mathrm{eV}$ is similar to the doped state reported by Xu et al. [27]. These results are interesting because they indicate that we can obtain nonmetal-doped $\mathrm{TiO}_{2}$ promising for visible light-driven photocatalysis using a facile sol-gel procedure.

The Ti $2 p$ spectrum in Fig. 3(c) contains two peaks at 458.72 and $464.36 \mathrm{eV}$ that are consistent with $\mathrm{Ti} 2 p_{3 / 2}$ and Ti $2 p_{1 / 2}$ signals, respectively, indicating the presence of $\mathrm{Ti}^{4+}$. The $01 \mathrm{~s}$ spectrum could be fitted into three peaks (Fig. 3(d)). The peaks at 529.62 and $530.63 \mathrm{eV}$ are ascribed to Ti-O and surface $-\mathrm{OH}$, respectively, and that at $532.18 \mathrm{eV}$ may be related to adsorbed $\mathrm{H}_{2} \mathrm{O}$ or the doping mode $[27,29]$.

\subsubsection{Optical analyses}

Fig. 4(a) shows the UV-vis diffuse reflectance spectra of ATT, $\mathrm{P} 25$, and the $\mathrm{C}-\mathrm{Cl}$-codoped $\mathrm{TiO}_{2} / \mathrm{ATT}$ composites obtained at different $\mathrm{pH}$ values. It is noteworthy that the $\mathrm{C}$-Cl-codoped $\mathrm{TiO}_{2} / \mathrm{ATT}$ composites absorb light well in the visible region (420-600 nm). The response of these composites to visible

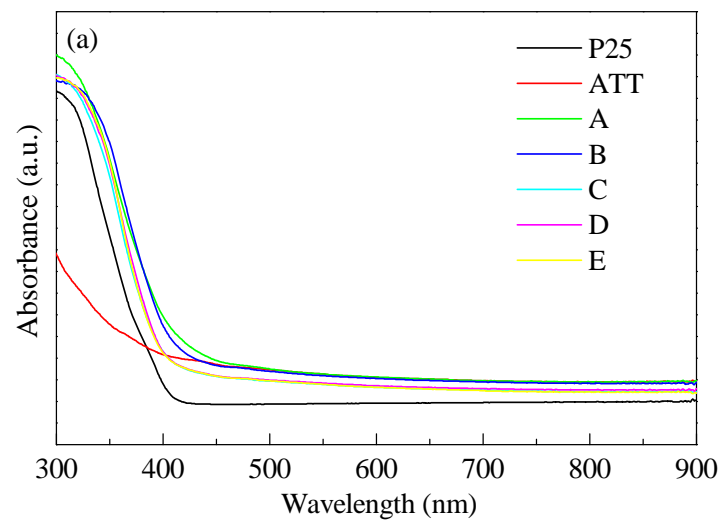

light might be attributed to the doping of $\mathrm{TiO}_{2}$ with $\mathrm{C}$ and $\mathrm{Cl}$, which could narrow the band gap of the $\mathrm{TiO}_{2}$ particles [30], or to an oxygen vacancy state between the valence band (VB) and conduction band [31]. The absorption edge of the $\mathrm{TiO}_{2} / \mathrm{ATT}$ composites appeared at around $600 \mathrm{~nm}$, from which their band gap was estimated to be about $2.07 \mathrm{eV}$. Such a narrow band gap is promising for application of the composites in dye degradation under visible or solar irradiation.

The Raman spectrum of a representative C-Cl-codoped $\mathrm{TiO}_{2}$ /ATT composite (sample B) is provided in Fig. 4(b), which confirms the presence of a mixture of phases of $\mathrm{TiO}_{2}$. First, the Raman band centered at $631 \mathrm{~cm}^{-1}$ is associated with the brookite phase [32]. Meanwhile, anatase $\mathrm{TiO}_{2}$ is reported to have six Raman-active modes $\left(\mathrm{A}_{1 \mathrm{~g}}+2 \mathrm{~B}_{1 \mathrm{~g}}+3 \mathrm{Eg}\right)$ that appear at 147,198 , $398,515,640$, and $796 \mathrm{~cm}^{-1}$, respectively, and rutile has four Raman-active modes A1g+B1g+B2g+Eg, which appear at 144, 448,612 , and $827 \mathrm{~cm}^{-1}$, respectively [33]. Consequently, the bands at 404 and $511 \mathrm{~cm}^{-1}$ in Fig. 4(b) can be assigned to the B1g and Eg modes of the anatase phases, respectively, while that at $151 \mathrm{~cm}^{-1}$ can be attributed to the $\mathrm{A} 1 \mathrm{~g}$ mode of the rutile or anatase phase. The result is consistent with the XRD characterization (Fig. 1).

\subsubsection{BET analysis}

Fig. 5(a) presents the $\mathrm{N}_{2}$ adsorption-desorption isotherms of

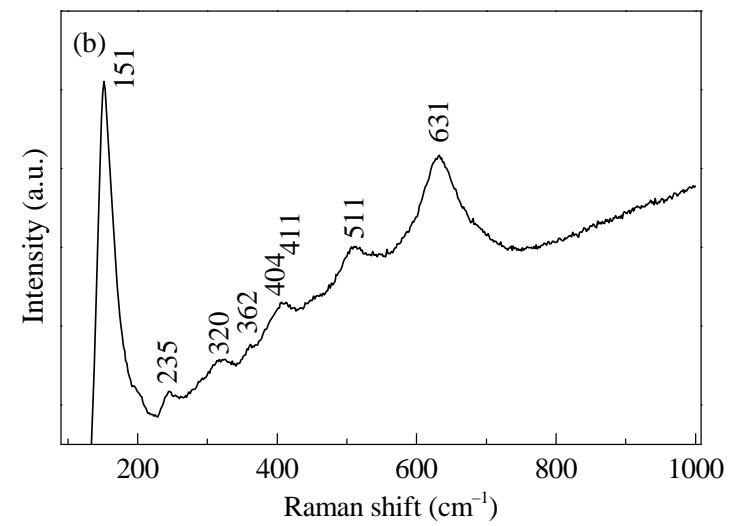

Fig. 4. (a) UV-vis absorption spectra of $\mathrm{P} 25$, $\mathrm{ATT}$, and the $\mathrm{C}$-Cl-codoped $\mathrm{TiO}_{2} / \mathrm{ATT}$ composites produced at different pH values. (b) Raman spectrum of the sample $B$.
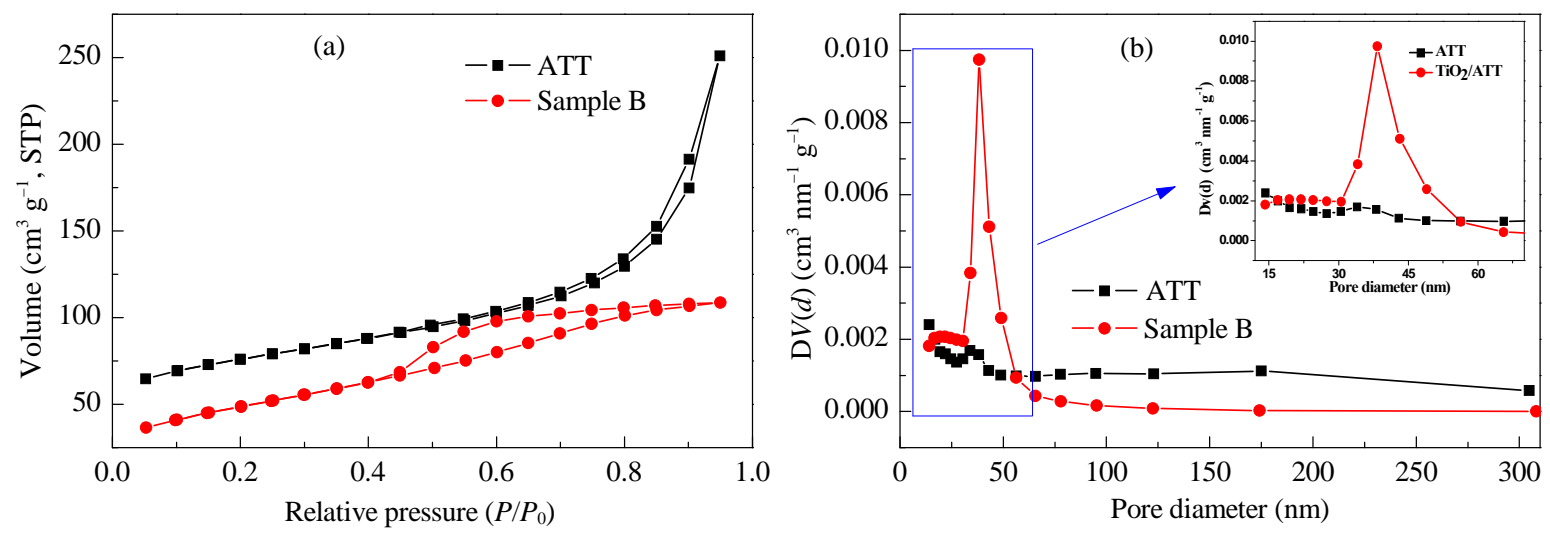

Fig. 5. (a) $\mathrm{N}_{2}$ adsorption-desorption isotherms; (b) BJH pore size distributions of ATT and sample B. 
ATT and sample B. A hysteresis loop is very common in the isotherms for this type of clay and is associated with the fiber network affecting $\mathrm{N}_{2}$ desorption [34]. The isotherm for ATT shows high adsorption at relative pressures $\left(P / P_{0}\right)$ approaching 1.0, suggesting the presence of large mesopores and macropores. Sample B exhibited a type-IV isotherm with a type-H3 hysteresis cycle (IUPAC) at $P / P_{0}$ above 0.4 (Fig. 5(a)), which indicates the presence of unique microstructure with mesopores [35]. The mesoporous structure was further evidenced from the pore size distribution (PSD) of sample B (Fig. 5(b)), which was centered at $37 \mathrm{~nm}$. The disappearance of the macropores observed in the initial ATT might be caused by the formation of $\mathrm{TiO}_{2}$ NPs. Mesoporous structure plays an important role in photocatalysis because it provides efficient transport pathways for reactant and product molecules [36].

The BET surface area, pore volume, and average pore size of ATT and sample B are summarized in Table 2. The introduction of $\mathrm{TiO}_{2}$ particles into ATT decreased its BET surface area, total pore volume, and average pore size. ATT had a BET surface area of $249.6 \mathrm{~m}^{2} / \mathrm{g}$, while after composite formation with $\mathrm{TiO}_{2}$, the BET surface area fell to $174.9 \mathrm{~m}^{2} / \mathrm{g}$. The decreases in surface area and pore volume were probably caused by the $\mathrm{TiO}_{2}$ NPs blocking the pore entrances of ATT [34].
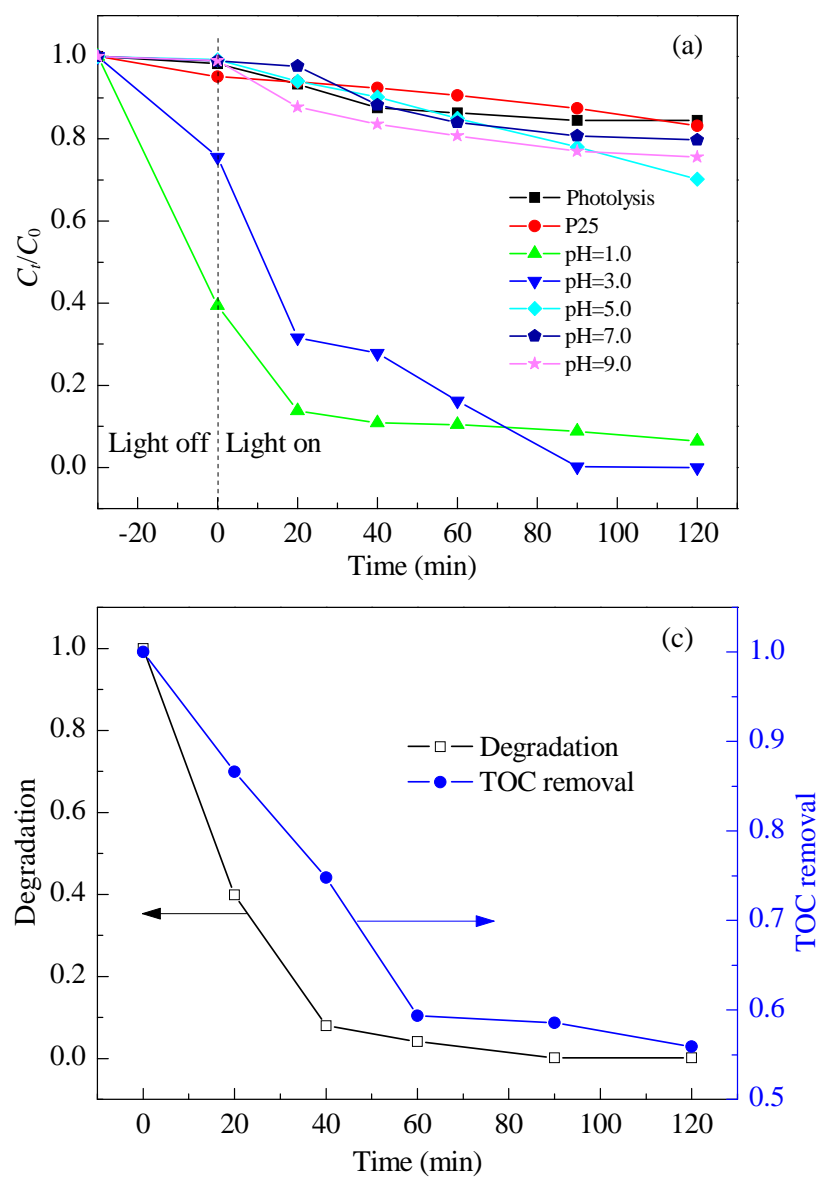

Table 2

Physical properties of ATT and sample B.

\begin{tabular}{lccc}
\hline Sample & $\begin{array}{c}\text { BET surface area } \\
\left(\mathrm{m}^{2} / \mathrm{g}\right)\end{array}$ & $\begin{array}{c}\text { Total pore volume } \\
\left(\mathrm{cm}^{3} / \mathrm{g}\right)\end{array}$ & $\begin{array}{c}\text { Average pore size } \\
(\mathrm{nm})\end{array}$ \\
\hline ATT & 249.6 & 0.39 & 6.2 \\
Sample B & 174.9 & 0.17 & 3.9 \\
\hline
\end{tabular}

\subsection{Photocatalytic activity}

Photolysis in the absence of photocatalyst under visible-light irradiation for 120 min led to a decrease of ARG concentration of only $8 \%$ (Fig. 6(a)). Conversely, marked decreases in ARG concentration were observed in the presence of photocatalysts and visible irradiation. Samples A and B displayed comparably high photocatalytic activity under visible irradiation, which was much higher than that of other samples prepared at $\mathrm{pH}$ above 3.0.

The higher photocatalytic activity of sample B compared with that of the other photocatalysts could be explained as follows. First, sample B exhibits stronger absorbance (relative to P25) in the visible region because of its codoping with $\mathrm{C}$ and $\mathrm{Cl}$. Second, sample B has excellent adsorption capacity for dye ARG molecules. As shown in Fig. 6(a), the concentration of ARG al-
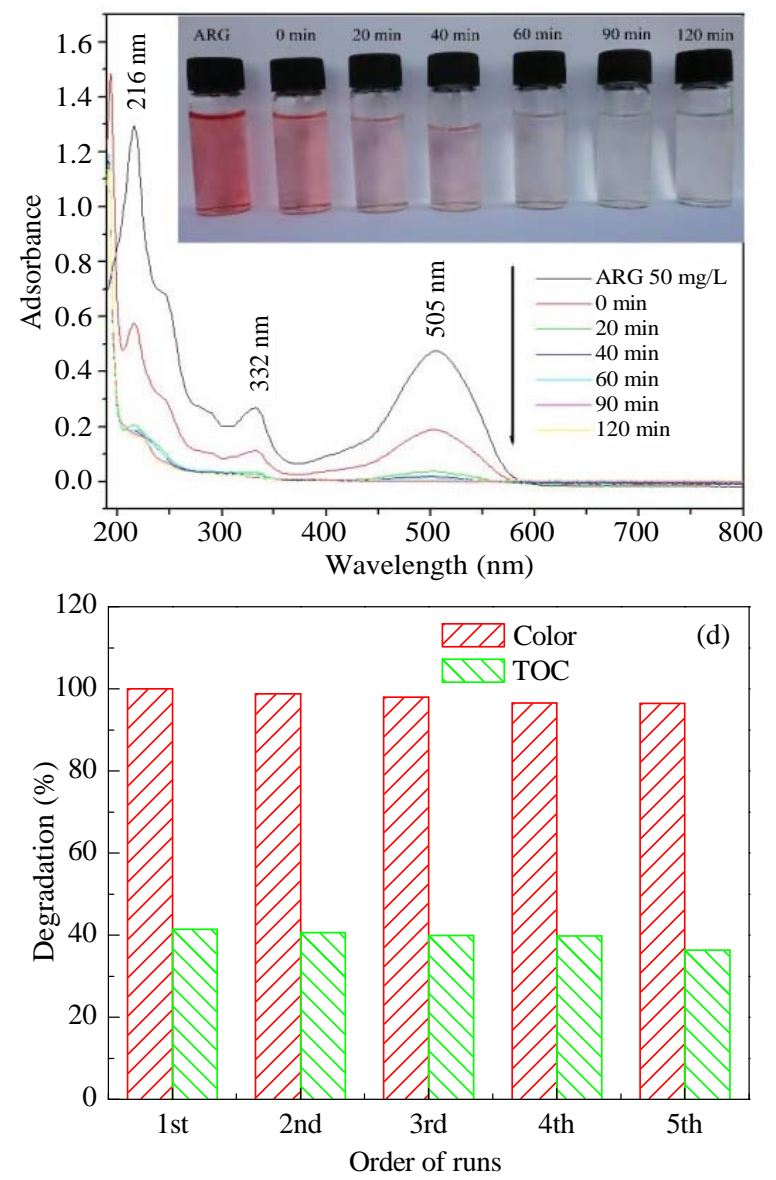

Fig. 6. (a) Photocatalytic degradation of ARG over P25 and C-Cl-codoped $\mathrm{TiO}_{2} / \mathrm{ATT}$ composites obtained at different pH values. (b) Evolution of the absorption spectra of ARG during photocatalysis over sample B. Inset is a photograph showing the color evolution of the ARG solution during irradiation. (c) Photodegradation and TOC removal of ARG over sample B at different irradiation times. (d) Photodegradation and TOC removal of ARG over sample B for five cycles. 
ready decreased by $60.2 \%$ before irradiation in the presence of sample $B$, which is caused by the adsorption of ARG on the $\mathrm{C}$-Cl-codoped $\mathrm{TiO}_{2} /$ ATT composite. This excellent adsorption capacity is favorable for the photocatalytic reaction. Indeed, 99\% of ARG was decomposed after 90 min under visible light-irradiation in the presence of sample B. Finally, it is widely accepted that mixed phases of a semiconductor are beneficial to lower the recombination of photogenerated electrons and holes and thus increase photocatalytic activity [30]. This could explain why sample B with a mixture of anatase $(41.07 \%)$, brookite $(37.76 \%)$, and rutile $(21.17 \%)$ phases displayed high photocatalytic activity for ARG degradation, consistent with the work of Paola et al. [23].

Fig. 6(b) shows the evolution of the absorption spectra of ARG solution during photocatalysis in the presence of sample B. The absorption spectrum of the original solution contains three characteristic peaks at 216, 332, and $505 \mathrm{~nm}$ that correspond to the benzene ring, naphthalene ring, and $\mathrm{N}=\mathrm{N}$ of $\mathrm{ARG}$, respectively. The observed decrease and disappearance of the three above-mentioned absorption peaks indicate that the $\mathrm{N}=\mathrm{N}$, benzene ring, and naphthalene ring of ARG were decomposed by the $\mathrm{C}$-Cl-codoped $\mathrm{ATT} / \mathrm{TiO}_{2}$ photocatalyst under visible irradiation. This is further evidenced by the FTIR analysis of the ATT, ARG, sample B, and sample B after visible light-induced catalysis (Fig. 7). The various characteristic peaks of ARG, such as the asymmetric stretching vibration of $\mathrm{N}-\mathrm{H}\left(3465 \mathrm{~cm}^{-1}\right)$, the aromatic skeletal vibrations of $\mathrm{C}=\mathrm{C}$ in the benzene ring (1497 $\mathrm{cm}^{-1}$ ), the $\mathrm{N}=\mathrm{N}$ vibration (1433 $\left.\mathrm{cm}^{-1}\right)$ [37], asymmetric stretching vibration of the methyl group $\left(1371 \mathrm{~cm}^{-1}\right)$, the vibration at $1042 \mathrm{~cm}^{-1}$ corresponding the stretching of $\mathrm{C}=0$ bonds [38], $\mathrm{CH}-$ bands $\left(832 \mathrm{~cm}^{-1}\right)$ [39], the ortho-disubstituted benzene nucleus on the naphthalene ring $\left(755 \mathrm{~cm}^{-1}\right)$, and $\mathrm{C}-\mathrm{C}$ stretch $\left(619 \mathrm{~cm}^{-1}\right)$ [40], vanished after $120 \mathrm{~min}$ of photocatalysis. The disappearance of the $\mathrm{C}-\mathrm{N}$ stretch at $1290 \mathrm{~cm}^{-1}$ was presumably caused by the oxidation of the amine substituent on the naphthalene moiety [37]. All these results are in agree-

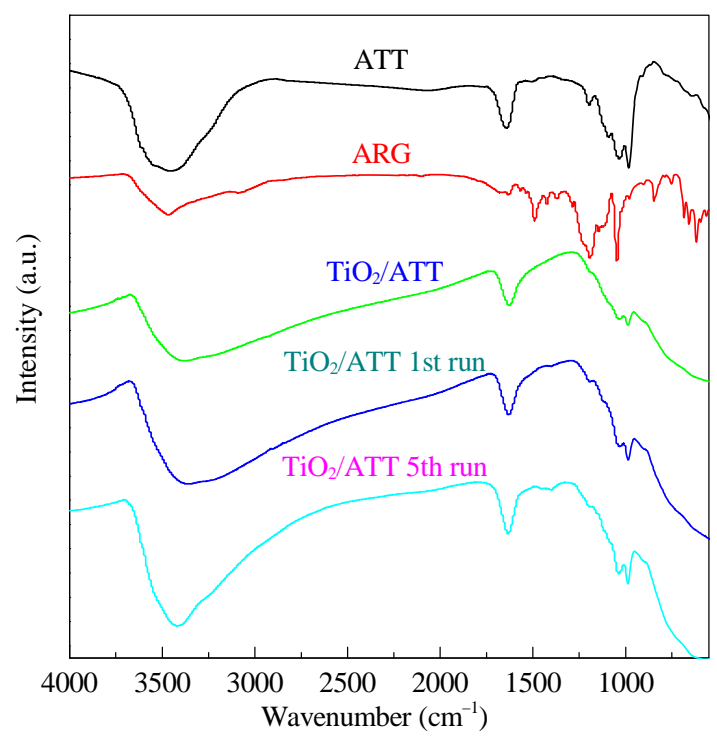

Fig. 7. FTIR spectra of ATT, acid red G (ARG), sample B, and sample B after photocatalysis for the first and 5 th cycles. ment with the evolution of the UV-Vis absorption spectra of ARG in Fig. 6(b).

The TOC removal of ARG was tested to evaluate the mineralizing capability by the photocatalyst. The ARG was completely decolored and $44 \%$ of the TOC was removed in 120 min under visible irradiation. The TOC removal was lower than the degradation of ARG (analyzed at the maximum absorption wavelength of ARG), indicating the formation of recalcitrant intermediates.

We recovered sample B after photocatalysis for further photocatalytic degradation of ARG under the same conditions to evaluate the stability of this photocatalyst (Fig. 6(d)). The discoloration and TOC removal of ARG reached $96.3 \%$ and $36.3 \%$, respectively, even after five photodegradation cycles, indicating little change of the photocatalytic efficiency of sample B. Furthermore, the FTIR spectra of this composite were almost the same before and after the five photocatalytic degradation cycles of ARG solution (Fig. 7). All these results indicate that the $\mathrm{C}$-Cl-codoped $\mathrm{ATT} / \mathrm{TiO}_{2}$ composite remained effective and stable during successive catalysis cycles under visible illumination.

\subsection{Proposed mechanism of photocatalysis}

\subsubsection{Mechanism of visible-light activity}

Based on the above results and discussion, we could attribute the visible-light activity of the $\mathrm{C}$-Cl-codoped $\mathrm{TiO}_{2} / \mathrm{ATT}$ composites to the $\mathrm{C}$ and $\mathrm{Cl}$ codoping and mixture of phases of $\mathrm{TiO}_{2}$. The nonmetal doping with $\mathrm{Cl}$ and $\mathrm{C}$ in our work, like the previously reported N-, F-, and S-doping of $\mathrm{TiO}_{2}$ [30], plays an important role in increasing the visible-light absorption of the $\mathrm{TiO}_{2}$ /ATT composites. In addition, the rutile phase of $\mathrm{TiO}_{2}$ acts as an antenna to extend its photoactivity into the visible region and the structural arrangement of similarly sized $\mathrm{TiO}_{2}$ crystallites creates catalytic "hot spots" (tetrahedral $\mathrm{Ti}^{4+}$ sites) at the rutile/anatase interface [41].

\subsubsection{Detection of active species during photocatalysis}

The photocatalytic decomposition of organic compounds might involve direct oxidation by the photoexcited holes ( $\mathrm{h}_{\mathrm{VB}}$ ) with sufficient oxidation power in the VB or in localized states within the band gap, decomposition by active species such as - $\mathrm{OH}$ that are generated by the reaction of $\mathrm{h}_{\mathrm{vB}}$ with surface-adsorbed water and hydroxyl groups [42], and/or the degradation by $\mathrm{O}_{2} \bullet$ generated by electrons reacting with $\mathrm{O}_{2}$ [43]. To figure out which species played a critical role in photocatalysis, we collected fluorescence spectra of $\mathrm{TiO}_{2} / \mathrm{ATT}$ solutions at different reaction times during the photodecomposition process (Fig. 8). It is known that $\bullet \mathrm{OH}$ can react with TA to generate 2-hydroxyterephthalic acid, which emits unique fluorescence at around $426 \mathrm{~nm}$ [44]. Indeed, fluorescence at around $426 \mathrm{~nm}$ was observed for the $\mathrm{TiO}_{2} / \mathrm{ATT} / \mathrm{TA}$ system, the intensity of which increased with irradiation time (Fig. 8(a)), indicating that the $\bullet \mathrm{OH}$ concentration increased accordingly. The ratio of $\bullet \mathrm{OH}$ generation rate $(v)$ to time $(t)$ was linear (Fig. $8(\mathrm{~b})$ ). These results indicate that $\bullet \mathrm{OH}$ is one of the main active species in the photocatalytic decomposition process of ARG. 

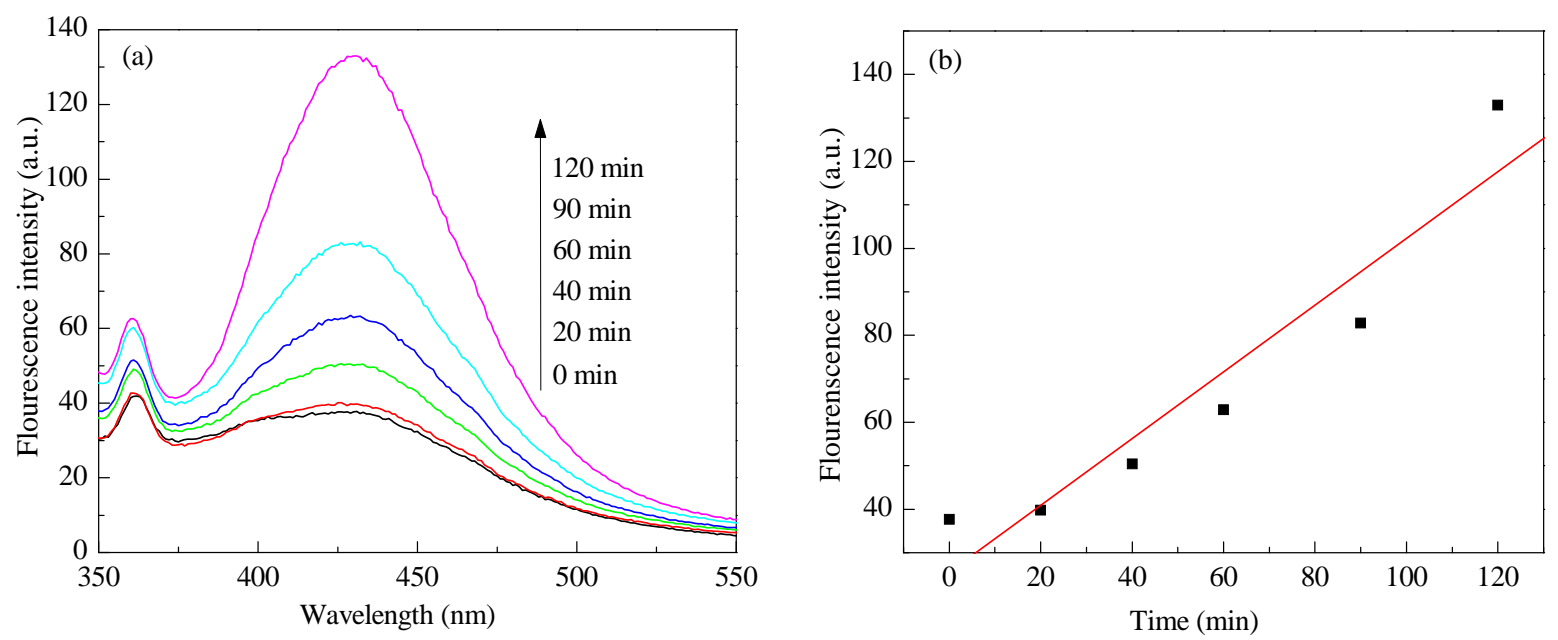

Fig. 8. (a) Hydroxyl radical trapping PL spectra of a $\mathrm{TiO}_{2} /$ attapulgite/terephthalic acid solution. (b) Plot of the induced PL intensity (at $\lambda=426 \mathrm{~nm}$ ) against irradiation time.

We further investigated the photodegradation of ARG in the presence of scavengers such as i-PrOH (for $\bullet \mathrm{OH}$ ) and $\mathrm{KI}$ (for both $\bullet \mathrm{OH}$ and $\mathrm{hvB}$ ) [45], and trapping of benzoquinone (BQ) for $\mathrm{O}_{2} \bullet$ [46]. The addition of i-PrOH (100 mmol/L), KI, or BQ led to marked suppression of the degradation of ARG (Fig. 9), which indicates that not only $\bullet \mathrm{OH}$ but also $\mathrm{h}_{\mathrm{vB}}$ and $\mathrm{O}_{2} \bullet$ were responsible for the decomposition of ARG.

\subsubsection{Possible reaction process}

The adsorption of ARG molecules by the photocatalysts is the first critical step in photocatalysis involving degradation of dyes for wastewater treatment. The mesoporous structure of the photocatalysts confirmed by the analysis of $\mathrm{N}_{2}$ adsorption/desorption isotherms and PSD enables the surface of the C-Cl-codoped $\mathrm{TiO}_{2} / \mathrm{ATT}$ to be accessible to solute molecules, which is advantageous in the adsorption of organic molecules [47].

In photocatalysis, it is of great importance to effectively separate the photoexcited electron/hole pairs, which could

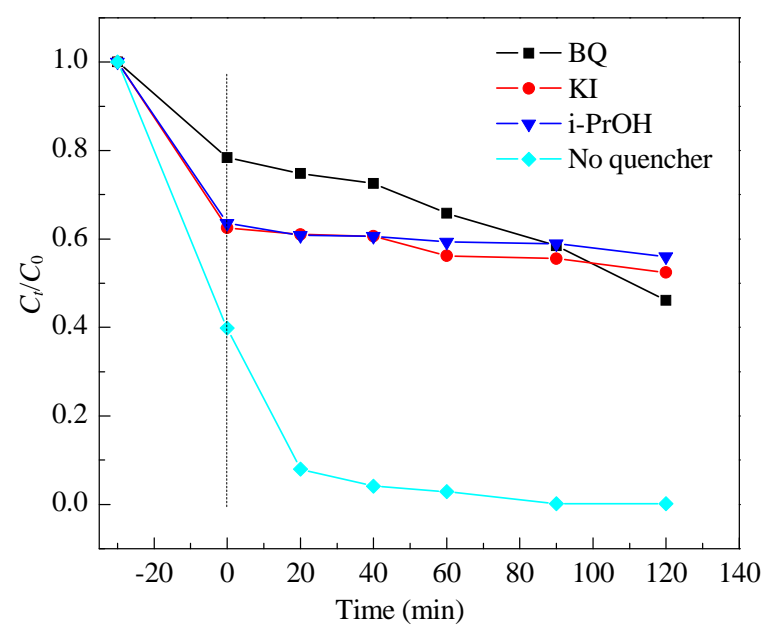

Fig. 9. Photocatalytic degradation of acid red $\mathrm{G}$ over the $\mathrm{C}-\mathrm{Cl}$-codoped $\mathrm{TiO}_{2}$ /ATT composite obtained at pH 3.0 (sample B) in different solutions. migrate to the NP surface of the $\mathrm{C}-\mathrm{Cl}$-codoped $\mathrm{TiO}_{2}$ /ATT for further redox reaction before recombination. The difference between the band edges of contacting different phases of $\mathrm{TiO}_{2}$ (e.g., anatase and rutile) promotes charge transfer from one phase to other ones [48]. In addition, the presence of rutile crystallites creates an interface where the electrons migrate from the rutile phase to lower-energy anatase lattice trapping sites under visible illumination, while the holes in the anatase phase transfer to the VB of the rutile phase. Thus, the holes are concentrated in the rutile phase and electrons are left in the anatase particles, which indicates that oxidation happens mostly on the rutile phase and reduction mostly on the anatase; that is, redox sites are separated [41]. Then, the holes migrating to the surface of the rutile NPs might directly oxidize organic pollutant molecules, or react with surface hydroxyl groups to generate reactive $\bullet \mathrm{OH}$, which would further attack and oxidize the organic molecules to produce intermediates and finally mineralize the organic species [49]. In addition, $\bullet \mathrm{OH}$ can also be formed through the reaction of photogenerated electrons with $\mathrm{O}_{2}$ molecules adsorbed on the anatase surface [48].

\section{Conclusions}

C-Cl-codoped $\mathrm{TiO}_{2} / \mathrm{ATT}$ composites were synthesized by a facile sol-gel method using TTIP as a $\mathrm{TiO}_{2}$ precursor. The photocatalyst produced at $\mathrm{pH} 3.0$ was composed of a mixture of three crystalline phases and showed strong optical absorption in the visible region. The composites exhibited excellent visible light-induced catalytic activity in the decomposition of ARG, and remained effective and stable during successive photodecomposition cycles. The promising properties and activity of the photocatalyst were mainly ascribed to the synergistic effect of its mesoporous structure, mixture of $\mathrm{TiO}_{2}$ phases, and codoping with $\mathrm{C}$ and $\mathrm{Cl}$. We found that $\bullet \mathrm{OH}, \mathrm{O}_{2} \bullet$, and $\mathrm{h}_{\mathrm{VB}}$ were the main reactive species in the photocatalytic degradation process. Our work suggests that $\mathrm{C}-\mathrm{Cl}$-codoped $\mathrm{TiO}_{2}$ /ATT composites are promising materials for photodegradation of organic pollutants under visible-light illumination. 


\section{References}

[1] D. D. Tang, G. K. Zhang, Appl. Surf. Sci., 2017, 391, 415-422.

[2] D. Lu, Z. Wan, G. K. Zhang, Appl. Surf. Sci., 2015, 358, 223-230.

[3] Z. Wan, G. K. Zhang, J. Mater. Chem. A, 2015, 3, 16737-16745.

[4] Q. L. Xu, J. G. Yu, J. Zhang, J. F. Zhang, G. Liu, Chem. Commun., 2015, 15, 7950-7953.

[5] X. Li, J. G. Yu, M. Jaroniec, Chem. Soc. Rev., 2016, 45, 2603-36.

[6] H. J. Huang, D. Z. Li, Q. Lin, Y. Shao, W. Chen, Y. Hu, Y. B. Chen, X. Z. Fu, J. Phys. Chem. C, 2009, 113, 14264-14269.

[7] W. J. Zhou, H. Liu, J. Y. Wang, D. Liu, G. J. Du, J. Cui, ACS Appl. Mater. Interfaces, 2010, 2, 2385-2392.

[8] Y. Du, D. D. Tang, G. K. Zhang, X. Y. Wu, Chin. J. Catal., 2015, 36, 2219-2228.

[9] H. Xu, L. Z. Zhang, J. Phys. Chem. C, 2009, 113, 1785-1790.

[10] S. Sakthivel, M. Janczarek, H. Kisch, J. Phys. Chem. B, 2004, 108, 19384-19387.

[11] H. G. Yu, H. Irie, Y. Shimodaira, Y. Hosogi, Y. Kuroda, M. Miyauchi, K. Hashimoto, J. Phys. Chem. C, 2010, 114, 16481-16487.

[12] W. H. Jing, W. G. Wang, X, W. H. Xing, Chin. J. Catal., 2009, 30, 426-432.

[13] I. C. Kang, Q. W. Zhang, S. Yin, T. Sato, F. Saito, Appl. Catal. B, 2008, 80, 81-87.

[14] F. Chen, W. W. Zou, W. W. Qu, J. L. Zhang, Catal. Commun., 2009, $10,1510-1513$.

[15] J. Liu, G. K. Zhang, Phys. Chem. Chem. Phys., 2014, 16, 8178-8192.

[16] W. J. Zhang, S. L. Zhu, Y. Li, F. H. Wang, H. B. He, Chin. J. Catal., 2007, 28, 269-273.

[17] Y. Ma, G. K. Zhang, Chem. Eng. J., 2016, 288, 70-78.

[18] T. C. An, J. X. Chen, G. Y. Li, X. J. Ding, G. Y. Sheng, J. M. Fu, B. X. Mai, K. E. O'Shea, Catal. Today, 2008, 139, 69-76.

[19] Y. S. Liu, P. Liu, Z. X. Su, F. S. Li, F. S. Wen, Appl. Surf. Sci., 2008, 255, 2020-2025.

[20] H. Z. Zhang, J. F. Banfield, J. Phys. Chem. C, 2007, 111, 6621-6629.

[21] G. K. Zhang, F. S. He, X. Zou, J. Gong, H. B. Tu, H. Zhang, Q. Zhang, Y. Liu, J. Alloys Compd., 2007, 427, 82-86.

[22] A. Pottier, C. Chanéac, E. Tronc, L. Mazerolles, J. P. Jolivet, J. Mater. Chem., 2001, 11, 1116-1121.

[23] A. D. Paola, M. Bellardita, R. Ceccato, L. Palmisano, F. Parrino, J. Phys. Chem. C, 2009, 113, 15166-15174.

[24] H. Q. Wang, Z. B. Wu, Y. Liu, J. Phys. Chem. C, 2009, 113, 13317-
13324.

[25] X. X. Wang, S. Meng, X. L. Zhang, H. T. Wang, W. Zhong, Q. G. Du, Chem. Phys. Lett., 2007, 444, 292-296.

[26] F. Dong, H. Wang, Z. B. Wu, J. Phys. Chem. C, 2009, 113, 1671716723.

[27] H. Xu, L. Z. Zhang, J. Phys. Chem. C, 2010, 114, 11534-11541.

[28] X. K. Wang, C. Wang, W. Q. Jiang, W. L. Guo, J. G. Wang, Chem. Eng. J., 2012, 189, 288-294.

[29] J. G. Yu, G. H. Wang, B. Cheng, M. H. Zhou, Appl. Catal. B, 2007, 69, 171-180.

[30] H. M. Luo, T. Takata, Y. G. Lee, J. F. Zhao, K. Domen, Y. S. Yan, Chem. Mater., 2004, 16, 846-849.

[31] Q. Xiao, J. Zhang, C. Xiao, Z. C. Si, X. K. Tan, Sol. Energy, 2008, 82, 706-713.

[32] S. J. Rigby, A. H. R. Al-Obaidi, S. K. Lee, D. McStay, P. K. J. Robertson, Appl. Surf. Sci., 2006, 252, 7948-7952.

[33] R. Z. Ma, K. Fukuda, T. Sasaki, M. Osada, Y. Bando, J. Phys. Chem. B, 2005, 109, 6210-6214.

[34] V. Belessi, D. Lambropoulou, I. Konstantinou, A. Katsoulidis, P. Pomonis, D. Petridis, T. Albanis, Appl. Catal. B., 2007, 73, 292-299.

[35] A. Nakahira, T. Kubo, Y. Yamasaki, ACS Appl. Mater. Interfaces, 2010, 2, 1136-1140.

[36] J. G. Yu, L. F. Qi, M. Jaroniec, J. Phys. Chem. C, 2010, 114, 1311813125.

[37] C. Nasr, K. Vinodgopal, L. Fisher, S. Hotchandani, A. K. Chattopadhyay, P. V. Kamat, J. Phys. Chem., 1996, 100, 8436-8442.

[38] J. Jang, H. S. Lee, W. S. Lyoo, Fiber. Polym., 2007, 8, 19-24.

[39] J. Bandara, J. A. Mielczarski, J. Kiwi, Langmuir, 1999, 15, 76807687.

[40] N. Biswas, S. Umapathy, J. Phys. Chem. A, 2000, 104, 2734-2745.

[41] D. C. Hurum, A. G. Agrios, K. A. Gray, T. Rajh, M. C. Thurnauer, J. Phys. Chem. B, 2003, 107, 4545-4549.

[42] G. Liu, C. H. Sun, L. Cheng, Y. G. Jin, H. F. Lu, L. Z. Wang, S. C. Smith, G. Q. Lu, H. M. Cheng, J. Phys. Chem. C, 2009, 113, 12317-12324.

[43] S. C. Yan, Z. S. Li, Z. G. Zou, Langmuir, 2010, 26, 3894-3901.

[44] G. Liu, L. Z. Wang, C. H. Sun, X. X. Yan, X. W. Wang, Z. G. Chen, S. C. Smith, H. M. Cheng, G. Q. Lu, Chem. Mater., 2009, 21, 1266-1274.

[45] L. M. Yang, L. E. Yu, M. B. Ray, Environ. Sci. Technol., 2009, 43, 460-465.

[46] J. Yang, C. C. Chen, H. W. Ji, W. H. Ma, J. C. Zhao, J. Phys. Chem. B, 2005, 109, 21900-21907.

\section{Graphical Abstract}

Chin. J. Catal., 2017, 38: 379-388 doi: 10.1016/S1872-2067(17)62774-8

Synthesis of C-Cl-codoped titania/attapulgite composites with enhanced visible-light photocatalytic activity

Lijuan Deng, Yi Xie*, Gaoke Zhang*

Wuhan University of Technology

The C-Cl-codoped $\mathrm{TiO}_{2}$ /ATT composites achieved by a facile sol-gel procedure exhibit much higher visible-light-induced degradation of acid red G than $\mathrm{P} 25 \mathrm{TiO}_{2}$ due to the extended visible absorbance and depression of the recombination of photoexcited electron/hole pairs.

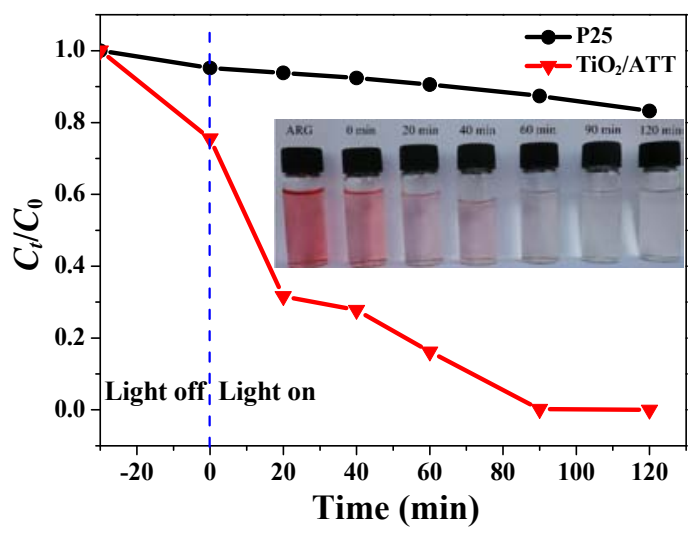


[47] S. K. Choi, S. Kim, S. K. Lim, H. Park, J. Phys. Chem. C, 2010, 114, 16475-16480.

[48] D. J. Yang, H. W. Liu, Z. F. Zheng, Y. Yuan, J. C. Zhao, E. R. Waclawik,
X. B. Ke, H. Y. Zhu, J. Am. Chem. Soc., 2009, 131, 17885-17893.

[49] L. F. Yin, J. F. Niu, Z. Y. Shen, J. Chen, Environ. Sci. Technol., 2010, 44, 5581-5586.

\section{$\mathrm{C}-\mathrm{Cl}$ 共掺杂 $\mathrm{TiO}_{2}$ /凹凸棒复合催化剂的制备及其可见光催化性能

\author{
邓丽娟, , , 谢 毅 $\mathbf{a}^{\mathrm{a}, \mathrm{t}}$, 张高科, , , , * \\ a武汉理工大学破酸盐建筑材料国家重点实验室, 湖北武汉 430070 \\ $\mathrm{b}^{\mathrm{y}}$ 汉理工大学资源与环境工程学院, 湖北省矿物资源加工与环境重点实验室, 湖北武汉 430070
}

摘要: $\mathrm{TiO}_{2}$ 光催化剂具有无毒、物理化学性质稳定及光催化活性较高等优点, 因而在能源及环境净化等领域备受关注. 但 是, $\mathrm{TiO}_{2}$ 纳米颗粒作为催化剂仍存在以下不足: (1) $\mathrm{TiO}_{2}$ 带隙较宽, 只能吸收利用太阳光能的紫外光部分, 而照射到地球表 面的太阳光大部分为可见光; (2) 光生载流子(电子/空穴)的复合使得光催化活性不高; (3) 纳米催化剂的回收利用困难; (4) 单独使用 $\mathrm{TiO}_{2}$, 成本较高; (5) 针对低浓度有机污染, 常见 $\mathrm{TiO}_{2}$ 催化剂比表面积较小, 吸附富集能力较差, 导致光催化降解 效率较低. $\mathrm{TiO}_{2}$ 自身这些缺陷大大限制了其进一步的实际应用.

针对上述这些问题, 我们在本研究中设计了一种简便易行的溶胶凝胶法, 在较低的温度 $\left(70^{\circ} \mathrm{C}\right)$ 下合成了非金属 $\mathrm{C}-\mathrm{Cl}$ 共 掺杂的 $\mathrm{TiO}_{2}$ /凹凸棒 $\left(\mathrm{TiO}_{2} / \mathrm{ATT}\right)$ 复合催化剂. XRD及HRTEM分析证明, 通过调节反应溶液的pH可以分别合成含锐钛矿/金 红石、锐铁矿/金红石/板钣矿的两相和三相的混合相 $\mathrm{TiO}_{2}$, 且锐钛矿/金红石比例可以通过改变 $\mathrm{pH}$ 而进行调节. XPS分析证 明, C和 Cl同时成功掺进 $\mathrm{TiO}_{2} / \mathrm{ATT}$ 复合催化剂. UV-Vis漫反射结果显示, 非金属C和Cl的掺杂使得所合成复合催化剂的光 吸收性能明显拓展到可见光区, 因而可以充分利用可见光能进行有机污染物催化降解, 而ATT作为 $\mathrm{TiO}_{2}$ 的载体, 减少了 $\mathrm{TiO}_{2}$ 使用量, 改善了 $\mathrm{TiO}_{2}$ 的表面特性和孔结构, 且有利于光催化剂的回收利用.

以酸性红G为目标有机污染物, 在可见光照射下对复合催化剂的可见光催化活性进行了测试. 结果表明, 当合成反应 体系的 $\mathrm{pH}$ 值为3.0时, 所获得的锐钛矿/金红石/板钛矿三相 $\mathrm{TiO}_{2} / \mathrm{ATT}$ 复合催化剂具有良好的可见光吸收特性, 其可见光催化 活性远远高于市售 $P 25$ 型 $\mathrm{TiO}_{2}$, 对难降解的酸性红溶液 $\mathrm{G}$ 具有优异的脱色效果和良好的 $\mathrm{TOC}$ 去除性能. 循环光催化实验和 FTIR表征结果表明, 在5次循环利用后, $\mathrm{TiO}_{2} / \mathrm{ATT}$ 复合催化剂仍表现出很高的催化活性, 表明其稳定性优异. 荧光分析和自 由基捕获实验表明, 光催化降解反应中的主要活性物种是羟基自由基、空穴和超氧自由基.

$\mathrm{TiO}_{2} / \mathrm{ATT}$ 复合催化剂高效稳定的可见光催化性能主要归因于: (1) 非金属 $\mathrm{C}$ 和 $\mathrm{Cl}$ 的共掺杂改善了其可见光吸收性能; (2) 催化剂中的 $\mathrm{TiO}_{2}$ 由金红石、锐钛矿和板钛矿混合相组成, 有利于抑制光生载流子的复合; (3) 多孔结构的ATT作为载体 提高了 $\mathrm{TiO}_{2}$ 的比表面积, 增加了反应活性位, 同时改善了孔结构, 从而有利于模拟有机污染物(酸性红G)分子的吸附和降解, 有利于反应产物扩散, 从而提高了催化剂的可见光催化效率.

关键词: 锐钛矿; 金红石; 板钛矿; 凹凸棒; 碳-氯共掺杂二氧化钛; 可见光

收稿日期: 2016-10-21. 接受日期: 2016-12-23. 出版日期: 2017-02-05.

*通讯联系人. 电话: (027)87651816; 传真: (027)87887445; 电子信箱: gkzhang@whut.edu.cn

\#通讯联系人. 电话: (027)87651816; 传真: (027)87887445; 电子信箱: xiey@whut.edu.cn

基金来源：国家重点基础研究发展计划(973计划, 2007CB613302); 湖北省自然科学基金(2016CFA078).

本文的英文电子版由Elsevier出版社在ScienceDirect上出版(http://www.sciencedirect.com/science/journal/18722067). 